\title{
Membangun Karakter Anak Melalui Pendidikan Karakter
}

\author{
Laila Maharani \\ Dosen Fakultas Tarbiyah Dan Keguruan, IAIN Raden Intan Lampung \\ Diterima: April 2014. Disetujui: Mei 2014. Dipublikasikan: Juni 2014
}

\begin{abstract}
Abstrak: Berbagai Bentuk Kejahatan Dan Tindakan Tidak Bermoral Di Kalangan Anak Dan Remaja Menunjukkan Bahwa Anak Didik Kita Belum Memiliki Karakter Yang Baik. Hal Ini Mengindikasikan Perlunya Pendidikan Karakter Yang Sesuai Untuk Anak, Yang Tidak Sekedar Pengetahuan Dan Doktrinasi, Tetapi Lebih Menjangkau Wilayah Emosi. Dalam Proses Pembentukan Manusia Berkualitas, Pendidikan Karakter Amat Diperlukan Agar Manusia Bukan Hanya Mengetahui Kebajikan (Knowing The Good), Tetapi Juga Merasakan (Feeling The Good), Mencintai (Loving The Good), Menginginkan (Desiring The Good) Dan Mengerjakan Kebajikan (Acting The Good).
\end{abstract}

Kata Kunci : Pendidikan Karakter, Otak Kiri

\section{Pendahuluan}

Anak merupakan individu yang unik, dan memiliki kekhasan tersendiri. Setiap anak yang lahir memiliki potensi yang sangat menakjubkan untuk dikembangkan. Hampir setiap hari kita disuguhi berita tentang tindakan amoral anak-anak dan remaja. Silih berganti televisi dan surat kabar memberitakan pemerkosaan yang korban maupun pelakunya siswa sekolah, mirasantika dikalangan remaja dan anak, tawuran antar sekolah, pengeroyokan, pencurian, dan pornografi yang ternyata $90 \%$ pelaku dan pembuatannya adalah remaja dan anak-anak.

Kondisi di atas tentu saja mencemaskan berbagai pihak, terutama orang tua dan pendidik. Thomas Lickona (Lickona, 1992) berpendapat bahwa terdapat sepuluh tanda perilaku manusia yang menunjukkan arah kehancuran suatu bangsa, yaitu: meningkatnya kekerasan dikalangan remaja; ketidak jujuran yang membudaya; semakin tingginya rasa tidak hormat kepada orangtua, guru, dan figur pemimpin; pengaruh peer group terhadap kekerasan; meningkatnya kecurigaan dan kebencian; penggunaan bahasa yang memburuk; penurunan etos kerja; menurunnya rasa tanggung jawab individu dan warga negara; meningginya perilaku merusak diri; dan semakin kaburnya pedoman moral.

Setiap orangtua ingin anak-anaknya cerdas dan berperilaku baik dalam kehidupan sehari-hari, sehingga mereka kelak akan menjadi anak-anak yang unggul dan tangguh menghadapi berbagai tantangan di masa depan. Perlu disadari bahwa generasi unggul semacam demikian ini tidak akan tumbuh dengan sendirinya. Mereka memerlukan lingkungan subur yang sengaja diciptakan untuk itu, yang memungkinkan potensi anak dapat tumbuh optimal sehingga menjadi lebih sehat, cerdas, dan berperilaku baik. Dalam hal ini orangtua dan pendidik memegang peranan yang amat penting.

Suasana penuh kasih sayang, mau menerima anak sebagaimana adanya, menghargai potensi anak, memberi rangsangan-rangsangan yang kaya untuk segala aspek perkembangan anak, baik secara kognitif, afektif maupun psikomotorik adalah beberapa hal yang perlu diperhatikan untuk membangun karakter anak.

Karakter mengacu pada serangkaian sikap (attitudes), perilaku (behaviors), motivasi (motivation), dan keterampilan (skills). (Abdul Aziz, 2011) Karakter meliputi sikap seperti keinginan untuk melakukan hal yang terbaik, kapasitas intelektual seperti berfikir kritis dan alasan moral dalam situasi penuh ketidakadilan, kecakapan interpersonal dan emosional yang memungkinkan seseorang berinteraksi secara efektif dalam berbagai keadaan, dan komitmen untuk berkontribusi dengan komunitas dan masyarakatnya. 
Dari beberapa pengertian di atas, dapat dikemukakan bahwa karakter adalah kualitas atau kekuatan mental dan moral, budi pekerti individu yang merupakan kepribadian khusus yang membedakan dengan individu lain. Dengan demikian dapat dikemukakan juga bahwa karakter pendidikan adalah kualitas atau kekuatan mental dan moral, budi pekerti dari nilainilai dan keyakinan yang ditanamkan dalam proses pendidikan yang merupakan kepribadian khusus yang harus melekat pada peserta didik.

Peserta didik dapat dikatakan berkarakter kuat dan baik jika telah berhasil menyerap nilai dan keyakinan yang telah ditanamkan dalam proses pendidikan serta digunakan sebagai kekuatan moral dan spiritual dalam kepribadiannya untuk menjalankan tugas dan kewajibannya mengelola alam (dunia) sehingga bermanfaat bagi kebaikan dirinya, keluarganya, masyarakat, dan alam semesta.

Pendidikan karakter merupakan upaya yang harus melibatkan semua pihak baik orangtua, keluarga, sekolah, dan lingkungan masyarakat. Pembentukan dan pendidikan karakter tidak akan berhasil selama antar lingkungan pendidikan tidak ada kesinambungan dan keharmonisan.

Dengan demikian orangtua dan keluarga sebagai lingkungan pembentukan dan pendidikan karakter pertama dan utama harus lebih diberdayakan. Sebagaimana disarankan Philips, orangtua dan keluarga hendaklah kembali menjadi school of love, sekolah untuk kasih sayang (Philips, 2001) atau tempat belajar yang penuh cinta sejati dan kasih sayang.

Sedangkan pendidikan karakter melalui sekolah, tidak semata-mata pembelajaran pengetahuan atau akademis, lebih dari itu yaitu penanaman moral, nilai- nilai etika, estetika, budi pekerti yang luhur dan sebagainya.

Pendidikan karakter tidak dapat dipisahkan dari identifikasi karakter yang digunakan sebagai pijakan. Karakter tersebut disebut sebagai pijakan. Karakter tersebut disebut sebagai karakter dasar. Tanpa karakter dasar, pendidikan karakter tidak akan memiliki tujuan yang pasti. Pendidikan karakter di Indonesia didasarkan pada sembilan pilar karakter dasar menjadi tujuan pendidikan karakter. Kesembilan pilar karakter dasar tersebut adalah: (1) cinta kepada Tuhan dan alam semesta beserta isinya, (2) tanggung jawab, disiplin dan mandiri, (3) jujur, (4) hormat dan santun, (5) kasih sayang, peduli, dan kerja sama, (6) percaya diri, kreatif, kerja keras dan pantang menyerah, (7) keadilan dan kepemimpinan, (8) baik dan rendah hati, serta 9) toleransi, cinta damai dan persatuan. Hal ini berbeda dengan karakter dasar yang dikembangkan di negara lain, serta karakter dasar yang dikembangkan oleh Ari Ginanjar (Ginanjar, 2007) melalui ESQ-nya. Perbedaan karakter dasar tersebut dapat dilihat pada tabel 1 berikut ini:

Tabel 1. Perbedaan karakter dasar pendidikan karakter

\begin{tabular}{|c|c|c|c|}
\hline \multicolumn{4}{|c|}{ KARAKTER DASAR } \\
\hline & Heritage Foundation & Character Counts & Ari Ginanjar \\
\hline 1. & Cinta kepada Tuhan & 1. Dapat dipercaya & 1. Jujur \\
\hline 2. & Tanggung jawab, disiplin, & Rasa hormat dan & Tanggung \\
\hline 3. & Jujur & Peduli (caring) & Disiplin \\
\hline 4. & Hormat dan Santun & Juiur (fairness) & Visioner \\
\hline 5. & Kasih savang, peduli, dan & Tanggung jawab & Adil \\
\hline \multirow[b]{2}{*}{6.} & Percaya diri, kreatif, kerja & 6. Kewarganegaraan & Peduli \\
\hline & $\begin{array}{l}\text { keras dan pantang } \\
\text { menyerah }\end{array}$ & $\begin{array}{l}\text { 7. } \begin{array}{l}\text { Ketulusan } \\
\text { (honesty) }\end{array} \\
\end{array}$ & \\
\hline 7. & $\begin{array}{l}\text { Keadilan dan } \\
\text { kepemimpinan }\end{array}$ & 8. Berani (courage) & \\
\hline 8 & Baik dan rendah hati & Tekun (diligence) & \\
\hline & $\begin{array}{l}\text { Toleransi, cinta cinta damai } \\
\text { dan persatuan }\end{array}$ & 10. Integritas & \\
\hline
\end{tabular}


Menurut (Lickona T. S., 2003) pendidikan karakter harus didasarkan pada sebelas prinsip berikut:

1. Mempromosikan nilai-nilai dasar etika sebagai basis karakter.

2. Mengidentifikasi karakter secara komprehensif supaya mencakup pemikiran, perasaan dan perilaku.

3. Menggunakan pendekatan yang tajam, proaktif dan efektif untuk membangun karakter.

4. Menciptakan komunitas sekolah yang memiliki kepedulian.

5. Memberi kesempatan kepada siswa untuk menunujukkan perilaku yang baik.

6. Memiliki kecakupan terhadap kurikulum yang bermakna dan menantang yang menghargai semua siswa, membangun karakter mereka dan membantu mereka untuk sukses.

7. Mengusahakan tumbuhnya motivasi diri pada para siswa.

8. Memfungsikan seluruh staf sekolah sebagai komunitas moral yang berbagi tanggung jawab untuk pendidikan karakter dan setia dengan nilai dasar yang sama.

9. Adanya pembagian kepemimpinan moral dan dukungan luas dalam membangun inisiatif pendidikan karakter.

10. Memfungsikan keluarga dan anggota masyarakat sebagai mitra dalam usaha membangun karakter.

11. Mengevaluasi karakter sekolah, fungsi staf sekolah sebagai guru- guru karakter, dan manifestasi karakter positif dalam kehidupan siswa.

Pendidikan karakter menurut Heritage Foundation bertujuan membentuk manusia secara utuh (holistik) yang berkarakter, yaitu mengembangkan aspek fisik, emosional, sosial, kreatifitas, spiritual dan intelektual siswa secara optimal. Salain itu, juga untuk membentuk manusia yang lifelong learners (pembelajar sejati). Strategi yang dapat dilakukan pendidik untuk mengembangkan pendidikan karakter adalah sebagai berikut:

1. Menerapkan metode belajar yang melibatkan partisipasi aktif siswa, yaitu metode yang dapat meningkatkan motivasi siswa karena seluruh dimensi manusia terlibat terlibat secara aktif dengan diberikan materi pelajaran yang kongkret, bermakna, serta relevan dalam konteks kehidupannya (student active learning, contextual learning, inquiry based learning, integrated learning).

2. Menciptakan lingkungan belajar yang kondusif (conducive learning community) sehingga anak dapat belajar dengan efektif di dalam suasana yang memberikan rasa aman, penghargaan, tanpa ancaman, dan memberikan semangat.

3. Memberikan pendidikan karakter secara eksplisit, sistematis, dan berkesinambungan dengan melibatkan aspek knowing the good, loving the good, dan acting the good.

4. Metode pengajaran yang memperhatikan keunikan masing- masing anak, yaitu menerapkan kurikulum yang melibatkan juga 9 aspek kecerdasan manusia.

5. Seluruh pendekatan diatas menerapkan prinsip-prinsip Developmentally Appropriate Practices.

6. Membangun hubungan yang supportive dan penuh perhatian di kelas dan seluruh sekolah, yang pertama dan terpenting adalah bahwa lingkungan sekolah harus berkarakteristik aman serta saling percaya, hormat, dan perhatian pada kesejahteraan lainnya.

7. Model (contoh) perilaku positif, bagian terpenting dari penataan lingkungan yang supportive dan penuh perhatian dan penuh perhatian di kelas adalah teladan perilaku penuh perhatian dan penuh penghargaan dari guru dalam interaksinya dengan siswa.

8. Menciptakan peluang bagi siswa untuk menjadi aktif dan penuh makna termasuk dalam kelas dan seluruh sekolah. Sekolah harus menjadi lingkungan yang lebih demokratis sekaligus tempat bagi siswa untuk membuat keputusan dan tindakannya. 
9. Mengajarkan keterampilan sosial dan emosional secara esensial. Bagian terpenting dari peningkatan perkembangan positif siswa termasuk pengajaran langsung keterampilan sosial-emosional, seperti mendengarkan ketika orang lain berbicara, mengenali dan mengelola emosi, menghargai perbedaan, dan menyelesaikan konflik melalui cara lemah lembut yang menghargai kebutuhan (kepentingan) masing- masing.

10. Melibatkan siswa dalam wacana moral. Isu moral adalah esensi pendidikan anak untuk menjadi prososial, moral manusia.

11. Membuat tugas pembelajaran yang penuh makna dan relevan untuk siswa.

12. Tak ada anak yang terabaikan. Tolok ukur yang sesungguhnya dari kesuksesan sekolah termasuk pendidikan 'semua' siswa untuk mewujudkan seluruh potensi mereka dengan membantu mereka mengembangkan bakat khusus dan kemampuan mereka, dan dengan membangkitkan pertumbuhan intelektual, etika, dan emosi mereka.

\section{Metode Penelitian}

Metode penelitian ini dilakukan dengan deskriptif kualitatif. Biasanya dalam penelitian antropologi menggunakan penelitian lapangan (observasi langsung), namun dalam tulisan ini menggunakan studi pustaka atau menggali data dari library research untuk memperkaya khasanah keilmuan bimbingan dan konseling.

\section{Hasil dan Pembahasan}

Berdasarkan sembilan karakter dasar menurut Heritage Foundation, maka dapat dibangun karakter sebagai berikut:

\section{A. Bertanggung Jawab}

Anak yang bertanggung jawab dapat melaksanakan apa yang dijanjikannya sehingga ia dapat dipercaya. Anak masing- masing bertanggung jawab atas perbuatan, perkataan, pemikiran, dan pilihan sendiri. Berikut adalah tiga langkah yang bisa membantu membuat pilihan-pilihan lebih baik:

1. Berpikirlah sebelum berbuat.

Sebelum memutuskan melakukan sesuatu, pikirkanlah apa yang mungkin terjadi setelahnya. Anak yang berpikir sebelum berbuat dapat terhindar dari masalah. Ia bisa saja berkata dalam hati: "Haruskah aku menelepon dulu ke rumah? Kalau aku tidak langsung pulang, nanti ibu khawatir atau marah. Bisa-bisa aku dihukum, atau mungkin ibu tidak percaya lagi kepadaku".

2. Kumpulkan fakta-faktanya

Selalu ada fakta untuk direnungkan. Anak bisa saja bertanya "Haruskah aku memberitahukan ibu dulu?" Tanyakanlah kepada anak "Apa sajakah pilihan yang ada?".

3. Putuskanlah pilihan mana yang paling baik bagi anak dan yang benar dilakukan.

Mempunyai banyak alternatif pilihan. Contoh: Anak memilih ikut temannya, padahal seharusnya ia bisa menolak. Seharusnya ia bisa menelepon dulu ke rumah. Mungkin ia malah bisa mengajak temannya ke rumah. Tetapi ia ingin temannya senang. Karenanya ia lupa bertanggung jawab terhadap dirinya sendiri. Pilihan terbaik itu tidaklah selalu yang paling mudah. Tetapi anak akan lebih baik seandainya ia telah memilih.

Orangtua dan pendidik dapat membantu anak membiasakan diri dengan membuat rencana harian atau akhir pekan seperti langkah- langkah berikut ini:

1. Tuliskan segala hal yang perlu anak kerjakan.

2. Tuliskanlah kapan masing-masing tugas itu harus dikerjakan.

3. Tuliskanlah hal-hal yang perlu anak kerjakan untuk masing-masing tugas tersebut.

4. Buatlah rencana cadangan. 
Berikut adalah contoh rencana yang bisa anak buat bagi dirinya sendiri:

\begin{tabular}{|c|c|c|c|}
\hline $\begin{array}{c}\text { Pekerjaan atau } \\
\text { Tugas }\end{array}$ & $\begin{array}{l}\text { Harus selesai } \\
\text { kapan }\end{array}$ & $\begin{array}{c}\text { Apa yang } \\
\text { kubutuhkan untuk }\end{array}$ & Rencana cadangan \\
\hline $\begin{array}{l}\text { Membaca buku } \\
\text { pelajaran hal } 12\end{array}$ & $\begin{array}{l}\text { Kamis (baca senin } \\
\text { malam) }\end{array}$ & $\begin{array}{l}\text { Ingat, } \\
\text { bukunya }\end{array}$ & $\begin{array}{l}\text { Baca selasa malam kalau } \\
\text { ternyata senin malam } \\
\text { diajak ayah ke acara }\end{array}$ \\
\hline $\begin{array}{l}\text { Membersihkan sisa } \\
\text { makanan kucing }\end{array}$ & $\begin{array}{l}\text { Senin, } \\
\text { Jum'at } \\
\text { (sebelum } \\
\text { nulans celsolob) }\end{array}$ & Tempat sampah baru & $\begin{array}{l}\text { Kerjakan setelah pulang } \\
\text { sekolah kalau pagi tidak } \\
\text { comnot }\end{array}$ \\
\hline
\end{tabular}

Cara untuk membuat pilihan-pilihan yang bertanggung jawab:

\section{H O I C E}

1. Renungkanlah (Consider) apa yang mungkin terjadi, berpikirlah sebelum berbuat.

2. Bantulah (Help) diri bertanggung jawab dengan membiasakan diri terorganisasikan.

3. Patuhilah (Obey) aturan-aturan dan hukum di rumah, di sekolah, dan di komunitas.

4. Abaikanlah (Ignore) ide-ide buruk yang muncul.

5. Gantilah apa yang sedang anak kerjakan atau pikirkanlah sesuatu yang baik sebagai gantinya.

6. Pilihlah (Choose) pilihan yang terbaik bagi anak maupun bagi

6 Alasan yang baik untuk mengatakan yang sebenarnya:

1. Mengatakan yang sebenarnya itu memungkinkan orang mengetahui apa yang sesungguhnya terjadi.

2. Mengatakan yang sebenarnya itu memungkinkan orang tidak disalahkan atas sesuatu yang tidak mereka perbuat.

3. Biasanya anak mengalami lebih sedikit masalah kalau mengatakan yang sebenarnya daripada kedapatan berbohong.

4. Teman-teman, orangtua, keluarga, dan guru-guru akan mempercayai anak dan hormat kepadanya kalau anak mengatakan yang sebenarnya.

5. Adalah lebih mudah mengatakan yang sebenarnya.

6. Mengatakan yang sebenarnya membantu anak merasa senang dan damai dalam hati.

B. Jujur

Anak telah bersikap jujur ketika ia mengatakan yang sebenarnya atau tidak berbohong dan memperlakukan orang lain secara adil. Tiga hal penting yang perlu orangtua dan pendidik lakukan untuk memberikan contoh agar anak bersikap jujur, yaitu: Bersikap apa adanya, bersikap tulus, dan bersikap dapat dipercaya. Berikut ini 6 cara yang seharusnya dilakukan orangtua dan pendidik. Cara untuk menjadi orang jujur:

\section{HONEST}

1. Pertahankanlah (Hold on) diri anda yang sesungguhnya. Selalu apa adanya tentang siapa anda.

2. Akuilah $(\boldsymbol{O} w n$ Up) kesalahan-kesalahan yang anda perbuat, seandainyapun anda takut mendapatkan masalah. Ingatlah bahwa berbohong itu menuntun anda kepada masalah yang lebih parah. 
3. Janganlah pernah (Never) berdiam diri kalau harus mengatakan yang sebenarnya. Kalau anda mengetahui tentang suatu kebohongan dan tidak mengatakan apapun, maka anda membiarkan kebohongan itu berlanjut.

4. Raihlah (Earn) kepercayaan sesama dengan memenuhi janji-janji anda kepada mereka dan dengan tidak pernah menipu.

5. Kembalikan apapun yang anda pinjam, dan janganlah pernah mengambil apapun tanpa meminta izin.

6. Berhenti (Stop) dan berpikirlah tentang apa yang sesungguhnya terjadi sehingga anda bisa menceritakannya dengan sebenarnya. Juga pikirkanlah tentang apa yang mungkin terjadi kalau anda tidak mengatakan yang sebenarnya.

7. Katakanlah ( $\boldsymbol{T}$ ell) kepada anak, bahwa anda telah berjanji untuk selalu mengatakan yang sebenarnya.

\section{Hormat Terhadap Sesama}

Sikap hormat adalah kepedulian yang khusus. Anda bisa menghormati orang yang anda kenal baik, dan juga orang yang sama sekali tidak anda kenal itu karena bagian dari sikap hormat adalah menghargai sesama manusia. Sikap hormat dapat ditunjukkan dengan cara: (1) Menghormati Diri Sendiri, (2) Menghormati Sesama (3) Menghormati Perbedaan (4) Menggunakan Tatakrama (5) Menghormati Harta Benda (6) Menghormati Alam dan Makhluk Hidup Lainnya (8) Menghormati Hukum, Kepercayaan, dan Adat Isiadat. Cara Untuk Menunjukkan Sikap Hormat:

\section{R E S P E C T}

1. Ulurkanlah (Reach out) tangan kepada sesama dan pelajarilah tentang kepercayaan dan adat istiadat mereka.

2. Nikmatilah (Enjoy) perbedaan diantara orang-orang, itulah yang menjadikan kehidupan menarik.

3. Tunjukkanlah (Show) sikap hormat terhadap aturan dan hukum dengan mematuhinya.

4. Gunakanlah (Put on) tatakrama yang sebaik mungkin. Berbicaralah dengan sopan, bantulah sesama, dan pilihlah kata-kata yang baik.

5. Makanlah (Eat) makanan yang bergizi, tidur dan olah raga yang cukup, pelajari kebiasaan-kebiasaan sehat, dan hormatilah dirimu sendiri.

6. Bersikaplah peduli (Care) terhadap tanaman, hewan, udara, dan air yang dibutuhkan makhluk hidup.

7. Perlakukanlah (Treat) harta benda kepunyaan sendiri atau pun kepunyaan orang lain dengan hati- hati

D. Peduli

Peduli adalah bagaimana anda saling memperlakukan sesama dengan baik. Menunjukkan kepedulian artinya bersikap baik hati, mau berbagi, menolong, dan memberi. Cara untuk menjadi semakin peduli:

\section{A R I N G}

1. Pedulikanlah (Care) anak. Bersikaplah baik hati, membantu, dan mau berbagi.

2. Tanyakanlah (Ask) kabar anak dan kegiatan anak hari itu. Jadilah pendengar yang baik.

3. Hormatilah (Respect) anak, sesama, harta benda, hewan, tumbuhan, serta bumi.

4. Libatkanlah (Include) anak dalam kegiatan yang bisa ia lakukan bersama. 
5. Jangan pernah (Never) mendendam.

6. Memberilah (Give). Bantulah anak merasa senang membantu orang lain.

E. Mandiri dan Percaya Diri

Kebebasan melakukan kebutuhan sendiri adalah mandiri. Berkat percaya diri, anak dapat melakukan sendiri kebutuhannnya, mempertimbangkan pilihannya dan membuat keputusan sendiri. Beberapa cara agar anak mandiri dan percaya diri:

1. Sebutkan beberapa hal yang dapat anak lakukan sendiri. Tanyakan bagaimana perasaan anak kerena mampu melakukan beberapa hal sendiri?

2. Sebutkan beberapa hal yang anak ingin dapat melakukannya sendiri. Tanyakan bagaimana anak belajar untuk melakukan hal itu?

3. Nyanyikanlah lagu anak dan menambahkan bait dengan keterampilan baru, mintalah anak memberikan versi tambahan. Bicarakan tentang berapa banyak anak telah belajar melakukan berbagai hal bagi dirinya sendiri dan betapa mandiriya mereka.

4. Pikirkan beberapa hal yang anak tidak pernah melakukannya sendiri.

5. Kembangkan keahlian bahasa anak dan teruskan diskusi tentang sikap mandiri dan percaya diri dengan melemparkan kata-kata berikut: Melakukan sendiri, Kebebasan, Mandiri, Percaya diri, Keputusan, Pilihan, kepercayaan.

6. Berikan anak kesempatan untuk memecahkan masalah dan membuat keputusan.

7. Biarkan anak melakukan beberapa hal sendiri.

8. Dukung dan bantulah anak untuk mandiri secepat mungkin.

9. Ajaklah bermain dan melakukan kegiatan yang dapat dimainkan sendiri.

10. Pujilah kemandirian anak.

F. Adil

Keadilan artinya memperlakukan sesama seperti yang anak ingin diperlakukan. Itu artinya berusaha memberi semua hak dan peluang seperti yang anak punyai. Untuk dapat bersikap adil, anda harus memperlakukan anak dengan sikap tidak memihak dan memperlakukan anak lain secara wajjar. Orang yang adil biasanya mempunyai pendangan jujur di dalam kehidupan sehari-hari dan di dalam situasi khusus. Beberapa cara agar anak dapat bersikap adil: Berbagi dan bergantian, putuskan untuk tidak cemburu, dan menghormati semua orang. Cara untuk memperlakukan sesama dengan adil:

\section{F a i r}

1. Temukanlah (Find) Cara-cara untuk berbagi, bergantian, dan tidak terlalu cemburu.

2. Tanyakanlah (Ask) kepada anak apa yang bisa anak perbuat untuk membnatu menjadikan segalanya lebih adil.

3. Libatkanlah (Involve) anak lain dalam permainan dan kegiatan anak.

4. Hormatilah (Respect) anak lain.

\section{G. Toleransi}

Toleransi adalah menghargai keberagaman manusia, berbagai nilai positif, serta bermacam peran manusia yang memiliki latar belakang, suku, agama, negara, dan budaya yang berbeda. Sikap toleransi merupakan kesiapan untuk saling menghormati perbedaan dan perilaku yang dimiliki orang lain, melalui proses belajar yang di cirikan dengan sikap menghormati, menerima perbedaan gender, etnik, ras, budaya, kelas sosial, agama, dan 
menghargai hak asasi manusia serta menghormati pentingnya hidup damai. Berbicara dengan anak mengenai beberapa ide tentang toleransi seperti di bawah ini:

1. Pikirkan mengenai sesuatu yang anak kerjakan atau percayai yang berbeda dengan temannya. Tanyakan bagaimana perasaan anak mengenai perbedaan ini?

2. Apakah pernah ada orang yang menertawakan anak karena anak berbeda? Bagaimana perasaannya? Dan apa yang ia lakukan?

3. Kembangkan keahlian bahasa anak dan teuskan diskusi tentang toleransi dengan melempar kata-kata berikut: Penerimaan, Penghargaan, Perbedaan, Seragam, Multikultural, Toleransi 4. Ketika anak berselisih dengan temannya, bantulah mereka mengenali perasaan mereka dan cobalah ajak anak membayangkan perasaan anak lainnya. Toleransi bermula dari menempatkan diri anak di tempat anak lain. Bacakanlah buku yang menawarkan kesempatan melihat sesuatu dari persfektif lain dan diskusikan bagaimana perbedaan tersebut.

4. Masukkan beberapa kegiatan yang terfokuskan pada pengenalan kesamaan dan perbedaan.

5. Doronglah anak untuk menggambarkan tradisi yang mereka lakukan dirumah, saat perayaan. Ajak anak untuk memperhatikan keseragaman cara merayakan pada hari yang sama dan juga kebebasan memilih yang terlibat di dalam suatu perayaan.

6. Doronglah anak mencoba sesuatu yang baru dan menerima aturan yang baru. Semakin banyak pengalaman yang mereka miliki, semakin luas wawasan mereka

H. Mau Bekerjasama

Kerjasama artinya bekerja atau bermain bersama dengan damai demi tercapainya tujuan umum. Bekerjasama untuk mencapai suatu sasaran adalah salah satu cara manusia bekerja. Berbicaralah dengan anak mengenai kerjasama seperti di bawah ini:

1. Apa yang pernah anak dan temannya lakukan bersama?

2. Nyanyikan "The More We Get Together". Bicarakan tentang banyak hal yang anak dapat lakukan bersama. Cari perbedaan antara melakukan sesuatu sendiri dan bekerja dalam kelompok.

3. Kegiatan apa yang anak lakukan di rumah atau di sekolah yang dibantu orang lain?

4. Pikirkan suatu pekerjaan yang setiap anggota keluarga dapat melakukannya. Apa yang terjadi jika hanya seorang yang melakukan semua pekerjaan tersebut? Dapatkah semua orang melakukan pekerjaan tersebut?

5. Buatlah daftar pekerjaan yang tidak dapat anak kerjakan sendiri.

6. Mainkan permainan yang

\section{Simpulan dan Saran}

Berbagai bentuk kejahatan dan tindakan tidak bermoral di kalangan anak dan remaja menunjukkan bahwa anak didik kita belum memiliki karakter yang baik. Hal ini mengindikasikan perlunya pendidikan karakter yang sesuai untuk anak, yang tidak sekedar pengetahuan dan doktrinasi, tetapi lebih menjangkau wilayah emosi. Dalam proses pembentukan manusia berkualitas, pendidikan karakter amat diperlukan agar manusia bukan hanya mengetahui kebajikan (knowing the good), tetapi juga merasakan (feeling the good), mencintai (loving the good), menginginkan (desiring the good) dan mengerjakan kebajikan (acting the good).

Metode pendidikan melalui otak kiri dengan hafalan konsep (memorization in learning), latihan mekanik dalam bentuk drill, harus diubah dengan metode yang lebih 
menekankan pada otak kanan dengan perasaan, cinta, serta pembiasaan dan amalan kebajikan di dalam keluarga maupun sekolah.

Pendidikan karakter sangat baik apabila telah dimulai sejak dini, termasuk dalam wilayah formal, informal, dan nonformal. Pendidikan karakter pada usia dini sangat membutuhkan contoh (modelling) dan pembiasaan dalam kehidupan sehari-hari (habit). Dalam wilayah pengetahuan emosi, pendidikan karakter dapat dilakukan melalui cara-cara yang sesuai Developmentally Appropriate Practices (DAP), yaitu pendidikan yang sesuai dengan tahapan perkembangan anak.

Kiranya uraian di atas dapat memberikan sedikit wawasan bagi orangtua dan pendidik untuk usaha membangun karakter anak sejak usia dini.

\section{Daftar Pustaka}

Abdul Aziz, H. (2011). Pendidikan Karakter Berpusat pada Hati. Jakarta: Al- Mawardi.

Alwisol, Psikologi Kepribadian, Malang, UMM, 2006

Battistic, Victor, Character Education, Prevention, and Positive Youth Development, Illinois: University of Missouri, St. Louis, 2007

Ginanjar, G. A. (2007). Rahasia Sukses Membangun Kecerdasan Emosi dan Spiritual: ESQ. Jakarta: Arga.

Law Nolte, Dorothy \& Haris Rachel, Children Learn What They Live (Terj), Batam, Interaksara, 2003

Lembaga Penelitian Universitas Negeri Yogyakarta, Character Building Tinjauan Berbagai Aspek, Yogyakarta, Tiara Wacana, 2008

Lewis.A, Barbara, Character Building untuk Anak-anak, Jakarta, Kharisma, 2004 Bantam Books, New York, 1992

Lickona, T, Schaps, E., \& Lewis, C, CEP's Eleven Principles of Effective Character Education, Washington, DC: Character Education Partnership, 2003

Lickona, T. (1992). Educating for Character, How Our Schools Can Teach Respect and Responsibility. New York: Bantam Books.

Lickona, T. S. (2003). CEP's Eleven Principles of Effective Character Education. Washington, DC: Character Education Partnership.

Megawangi, Ratna, Membangun SDM Indonesia melalui Pendidikan Holistik Berbasis Karakter, Versi Web, 2006

Philips, S. U. (2001). Participant structures and communicative competence: Warm Springs children in community and classroom.

Priyatna, Andri, Parenting for Character Building, Jakarta, Elex Media, 2011

Schiller, Pam, \& Bryant Tamera, 16 Moral Dasar Bagi Anak, Jakarta, Elex Media, 2002

Sujiono, Bambang, \& Nurani Yuliani Sujiono, Mencerdaskan Perilaku Anak Usia Dini, Jakarta, Elex Media, 2005

Tillman, Diane, Living Values Parent Groups: A Facilitator Guide, Jakarta, Grasindo, 2004 